\title{
BOOKS THAT MATTER
}

A book is an effective way to communicate ideas, lessons, and experiences beyond their times. The following is a partial list that greatly impacted my thinking:

1. The General, C.S. Forester, 1978

Treats how senior leaders with unimaginative direction and total incompetence can lead to appalling slaughter and devastating national economic consequences.

2. The Systems Approach, C. West Churchman, 1968 One of the seminal books on the impact of systems thinking and the systems approach on addressing complexity.

3. The Fifth Discipline: The Art \& Practice of The Learning Organization, Peter M. Senge, 1990 Systems approaches that enhance learning in an organization.

4. Intellectual Capital: The New Wealth of Organizations, Thomas A. Stewart, 1997

Redefines the priorities of businesses demonstrating that the most important assets are the knowledge of workers and all the past experiences a company has in its institutional memory. 
5. Consilience: The Unity of Knowledge, Edward O. Wilson, 1998 An original work of synthesis ... to unify all major branches of knowledge under the banner of science.

6. The Story of Philosophy, Bryan Magee, 1998 The complete guide to 2,500 years of western philosophy, from Ancient Greece to the present day.

7. Who Moved My Cheese, Spencer Johnson, M.D., 1998 Deals with change and its effects on human and organizational behavior.

8. Simplicity: The New Competitive Advantage, Bill Jensen, 2000

Treats how the ability to simplify complexity leads to competitive advantage.

9. Good to Great, Jim Collins, 2001

Research showing how long-term sustained performance can be engineered into the DNA of an enterprise from the very beginning.

10. The Wealth of Knowledge, Thomas A. Stewart, 2001 Reveals how companies are applying the concept of intellectual capital to the day-to-day operations to dramatically increase their success in the marketplace.

11. The World Is Flat, Thomas L. Friedman, 2005

A definitive work on how globalization came about, and the technological advancements that spawned this revolution.

12. The Definitive Drucker, Elizabeth Haas Edersheim, 2007 A summary of the lifetime of insights by the Father of Management, narrated by Dr. Drucker himself (right before his passing) to Mrs. Edersheim. 
13. Maestro, Roger Nierenberg, 2009 The incredible power of leading by listening.

14. The Corner Office, Adam Bryant, 2011 Indispensable and unexpected lessons from CEOs on How to Lead and Succeed. 